Holton, F. A., Hülsmann, W. C., Myers, D. K. \& Slater, E. C. (1957). Biochem. J. 67, 579.

Huseby, R. A. \& Barnum, C. P. (1950). Arch. Biochem. 26, 187.

Jervell, K. F., Diniz, C. R. \& Mueller, G. C. (1958). J. biol. Chem. 231, 845.

Jordan, W. K. \& March, R. (1956). J. Histochem. Cytochem. 4, 301.

Kearney, E. B. \& Singer, T.P.(1956). J.biol.Chem.219,963.

Longwell, B. B. \& Reif, A. E. (1955). Arch. Biochem. Biophys. 58, 92.

Needham, D. M. \& Cawkwell, J. M. (1956). Biochem. J. 63, 337.

Needham, D. M. \& Cawkwell, J. M. (1957). Biochem. J. 65, 540.

Nordmann, J., Nordmann, R. \& Gauchery, O. (1951). Bull. Soc. Chim. biol., Paris, 33, 1826.

Palade, G. E. \& Siekevitz, P. (1956a). J.biophys. biochem. Cytol. 2, 171.

Palade, G. E. \& Siekevitz, P. (1956b). J. biophys. biochem. Cytol. 2, 671.

Perry, S. V. (1952). Biochim. biophys. Acta, 8, 499.
Perry, S. V. \& Grey, T. C. (1956). Biochem. J. 64, 184.

Perry, S. V. \& Zydowo, M. (1959a). Biochem. J. 71, 220.

Perry, S. V. \& Zydowo, M. (1959b). Biochem. J. 72, 682.

Pressman, B. C. (1955). Biochim. biophys. Acta, 17, 273.

Reynolds, S. R. M. (1949). Physiology of the Uterus. New York: Paul B. Hoeber Inc.

Schneider, W. C. \& Hogeboom, G. H. (1951). Cancer Res. $11,1$.

Schneider, W. C., Hogeboom, G. H. \& Ross, H. E. (1950). J. nat. Cancer Inst. 10, 977.

Shoenberg, C. F. (1958). J. biophys. biochem. Cytol. 4, 609.

Sinclair, R. G. (1934). Physiol. Rev. 14, 351.

Telfer, M. A. (1953). Arch. Biochem. Biophys. 44, 111.

Thomson, R. Y., Heagy, F. C., Hutchison, W. C. \& Davidson, J. N. (1953). Biochem. J. 53, 460.

Vendrely, R. \& Vendrely, C. (1949). Experientia, 5, 327.

Volkin, E. \& Cohn, W. E. (1954). Meth. biochem. Anal. 1, 287.

Wakid, N. W. (1960). Biochem. J. 76, 88.

Wakid, N. W. \& Kerr, S. E. (1955). J.Histochem. Cytochem. 3, 75 .

Biochem. J. (1960) 76, 102

\title{
Some Aspects of the Metabolism of 5-Hydroxytryptamine
}

\author{
BY B. T. CHADWICK AND J. H. WILKINSON \\ Department of Chemical Pathology, Westminster Medical School (University of London), London, S.W. 1
}

(Received 31 December 1959)

The conversion of 5-hydroxytryptamine into 5hydroxyindolyl-3-acetic acid by kidney and liver preparations is initiated by monoamine oxidase (Blaschko, 1952; Titus \& Udenfriend, 1954), but there are indications that other enzymes may also be concerned with the metabolism of this base. For example, Dalgliesh \& Dutton (1957) detected a number of unidentified indole derivatives after the perfusion of rat liver with 5-hydroxytryptamine and a number of compounds other than 5-hydroxyindolyl-3-acetic acid have been found in the urines of patients with malignant carcinoid disease characterized by high circulatory levels of 5-hydroxytryptamine (Snow, Lennard-Jones, Curzon \& Stacey, 1955). Some of these substances might have arisen by entirely different metabolic pathways, and the present work was undertaken to investigate these possibilities.

A preliminary account of the results obtained when rat-liver preparations were incubated with 5-hydroxytryptamine has already appeared (Chadwick \& Wilkinson, 1958).

\section{EXPERIMENTAL}

5-Hydroxytryptamine base. A solution of 5-hydroxytryptamine creatinine sulphate (May and Baker I.td.,
$300 \mathrm{mg}$.) in $0.5 \mathrm{M}$-sodium borate buffer (pH 9-8; $30 \mathrm{ml}$.) was saturated with sodium chloride and the base extracted three times with butanol $(20 \mathrm{ml}$.). The solvent was removed under $3 \mathrm{~mm}$. $\mathrm{Hg}$ pressure and the residue dried at $20^{\circ}$. Yield: $90 \mathrm{mg}$.

Metabolism of 5-hydroxytryptamine by rat-liver homogenates. Male Wistar albino rats (100-150 g.), fed on M.R.C. cubed diet no. 41 (Bruce \& Parkes, 1949) and tap water without restriction, were killed by neck dislocation. The venae cavae were cut to exsanguinate the livers, which were quickly removed and weighed in Sørensen 0.067 Mphosphate buffer (pH 7.4; $5 \mathrm{ml}$.) at $0-5^{\circ}$. Sufficient buffer was then added to give a buffer:liver ratio of $2: 1$ and the mixture was homogenized in a cold, Monel-metal Ato-Mix 100 homogenizer for $1 \frac{1}{2} \mathrm{~min}$. The whole procedure occupied about $10 \mathrm{~min}$.

The homogenate $(18 \mathrm{ml}$.) was shaken with $0.01 \mathrm{M}-5$ hydroxytryptamine creatinine sulphate $(2 \mathrm{ml}$.) in a Braun rotary Warburg apparatus at $37^{\circ}$ in $\mathrm{O}_{2}$ for $2 \mathrm{hr}$. The mixture was cooled to $0^{\circ}$ and acidified to $\mathrm{pH} \mathrm{4-5}$ with $50 \%$ $(\nabla / \nabla)$ acetic acid. After $5 \mathrm{~min}$. the mixture was centrifuged at $500 \mathrm{~g}$ for $15 \mathrm{~min}$. Control preparations containing boiled homogenates and 5-hydroxytryptamine creatinine sulphate were similarly treated.

Indole derivatives were extracted from the supernatant by an adaptation of the method used by Dalgliesh (1956) for the isolation of urinary indoles. Charcoal (1 g.), partially deactivated with stearic acid, was shaken with the supernatant for $15 \mathrm{~min}$. and separated by filtration. It 
was washed three times with water $(100 \mathrm{ml}$.), thoroughly drained and then eluted with aqueous $6 \%(\mathrm{w} / \mathrm{v})$ phenol $\left(150 \mathrm{ml}\right.$.) at $5^{\circ}$ overnight. The eluate was filtered and the solvent removed by distillation under $3 \mathrm{~mm}$. $\mathrm{Hg}$ pressure (bath temp. $85^{\circ}$ ). Water $(20 \mathrm{ml}$.) was added to the residue and distilled to remove the last traces of phenol. The residue was dissolved in water $(2 \mathrm{ml}$.) and $20 \mu \mathrm{l}$. samples were chromatographed on Whatman no. 1 paper in two or more of the following solvent systems: (1) butanol-acetic acidwater (4:1:5, by vol.); (2) aqueous $20 \%(\mathrm{w} / \mathrm{v}) \mathrm{KCl}$; (3) butanol-pyridine-water (1:1:1, by vol.); (4) propan-2-olaqueous $6 \mathrm{~N}$-ammonia $(20: 3, \mathrm{v} / \mathrm{v})$. The chromatograms were dried at room temperature and examined in ultraviolet light after treatment with ninhydrin (Jepson \& Stevens, 1953).

Other chromatograms were stained with one of the following reagents for the detection of indole derivatives: Ehrlich's $p$-dimethylaminobenzaldehyde reagent (Jepson, 1955), diazotized sulphanilic acid, 1-nitroso-2-naphthol and nitrous acid (Udenfriend, Titus \& Weissbach, 1955).

Fractionation of rat-liver homogenates. A $10 \%(\mathrm{w} / \mathrm{v})$ ratliver homogenate in $0.25 \mathrm{M}$-sucrose was fractionated by differential centrifuging in silicone-treated glassware according to the method of Hogeboom (1955). Supernatant fractions were collected (a) after $15 \mathrm{~min}$. at $900 \mathrm{~g}$; (b) after $15 \mathrm{~min}$. at $8000 \mathrm{~g}$, and (c) after $30 \mathrm{~min}$. at $24000 \mathrm{~g}$, the temperature being maintained at $0-3^{\circ}$ throughout. Supernatant $(c)$ was further fractionated by precipitation with $\left(\mathrm{NH}_{4}\right)_{2} \mathrm{SO}_{4}$ (De Meio, Wizerkaniuk \& Schreibman, 1955). The precipitate produced by $1 \cdot 7 \mathrm{M}-\left(\mathrm{NH}_{4}\right)_{2} \mathrm{SO}_{4}$ was removed by centrifuging $\left(500 \mathrm{~g}\right.$ for $10 \mathrm{~min}$. at $\left.3^{\circ}\right)$. $\left(\mathrm{NH}_{4}\right)_{2} \mathrm{SO}_{4}$ was added to the supernatant to adjust the concentration to $3.5 \mathrm{M}$ and the resulting precipitate, collected by centrifuging at $0-3^{\circ}$, was dissolved in Sørensen $0.067 \mathrm{M}$-phosphate buffer, $\mathrm{pH} 7 \cdot 4$. $\left(\mathrm{NH}_{4}\right)_{2} \mathrm{SO}_{4}$ was removed by overnight dialysis at $4^{\circ}$ against the same buffer (2 l.).

Arylsulphatase preparations. A crude acetone-dried powder of rat liver was prepared by the method of Dodgson \& Spencer (1953). Rat livers (66 g.) were macerated with acetone $\left(200 \mathrm{ml}\right.$.) at $0^{\circ}$ for $2 \mathrm{~min}$. in a Monel-metal homogenizer. The macerate was filtered and the filtrate discarded. This process was repeated with two further $200 \mathrm{ml}$. portions of acetone at $0^{\circ}$ and the residue was dried at $20 \pm 2^{\circ}$ under $3 \mathrm{~mm}$. $\mathrm{Hg}$ pressure. Yield: $19 \mathrm{~g}$. of dried powder.

A soluble arylsulphatase fraction was prepared by extracting the acetone-dried powder (10 g.) with $0.1 \mathrm{M}-\mathrm{KCl}$ (200 ml.) and centrifuging at $500 \mathrm{~g}$ for $15 \mathrm{~min}$. (Roy, 1956). This and all subsequent operations were carried out at $0-5^{\circ}$. The supernatant was combined with that from a second extraction with $0 \cdot 1 \mathrm{M}-\mathrm{KCl}(200 \mathrm{ml}$.) and acidified to $\mathrm{pH} \mathrm{2-5}$ by the dropwise addition of $\mathrm{N}-\mathrm{HCl}$. After $1 \mathrm{~min}$. the $\mathrm{pH}$ of the solution was adjusted to $5 \cdot 1$ by means of M-sodium acetate, and the mixture was then treated with acetone $(250 \mathrm{ml}$.) and set aside for $15 \mathrm{~min}$.

The precipitate was collected by centrifuging at $500 \mathrm{~g}$ for $15 \mathrm{~min}$. and dried at $5^{\circ}$ over silica gel. Yield: $0.6 \mathrm{~g}$. of dried powder.

Quantitative excretion studies with 5-hydroxytryptamine. The required dose of 5-hydroxytryptamine creatinine sulphate in sterile water (1 ml.) was injected intraperitoneally into male Wistar albino rats (100-160 g.) fed on cubed diet no. 41 (Bruce \& Parkes, 1949) and tap water without restriction. Groups of three animals were kept in meta- bolism cages from which the urine was collected daily. The urine was acidified to $\mathrm{pH} \mathrm{4-5}$ with $50 \%(\mathrm{v} / \mathrm{v})$ acetic acid and stored at $5^{\circ}$ while awaiting analysis.

In some experiments the animals were pretreated with intraperitoneal 1-isopropyl-2-isonicotinylhydrazide phosphate (iproniazid) $(20 \mathrm{mg} . / \mathrm{kg}$.) in sterile water $(1 \mathrm{ml}) .2 \mathrm{hr}$. before the 5 -hydroxytryptamine, whereas in others sterile $1 \%(\mathrm{w} / \mathrm{v}) \mathrm{Na}_{2} \mathrm{SO}_{4}(1 \mathrm{ml}$.) was injected intraperitoneally $2 \mathrm{hr}$. before and $2 \mathrm{hr}$. after the 5 -hydroxytryptamine. A sample of the urine (half of the total volume) was removed for the determination of 5-hydroxyindolylacetic acid by the method of Udenfriend et al. (1955). The remainder was treated with charcoal, partially deactivated with stearic acid, followed by elution of the adsorbed indoles with aqueous phenol as described above. The 5-hydroxyindole derivatives were separated by unidimensional paper chromatography with Whatman no. 3MM paper and butanol-acetic acid-water (4:1:5, by vol.). A $2 \mathrm{~cm}$. strip was cut from the edge of the dried chromatograms and dipped in Ehrlich's reagent to locate the positions of the indole derivatives. The corresponding areas on the unstained part of the chromatogram were cut out and eluted with water $(10 \mathrm{ml}$.). The eluates were filtered and the indole derivatives were estimated in each fraction by measuring extinctions at $275 \mathrm{~m} \mu$ in $1 \mathrm{~cm}$. silica cells with a Unicam SP. 500 spectrophotometer. Comparison was made with eluates from chromatograms containing known amounts of 5-hydroxytryptamine and 5-hydroxyindolyl-3-acetic acid.

Excretion studies with 5-hydroxytryptophan. A solution of 5-hydroxy-DL-tryptophan (Roche Products Ltd.) (10 mg.) in water $(1 \mathrm{ml}$.) was injected intraperitoneally into each of six rats (200 g.) which were kept in a metabolism cage. The urine was collected over a period of $48 \mathrm{hr}$. and tested for indole derivatives by paper chromatography as described above.

Urines from patients with malignant carcinoid disease. Samples $(100 \mu \mathrm{l}$.) from $24 \mathrm{hr}$. specimens preserved with thymol were examined by direct two-dimensioral paper chromatography with the solvent systems recommended by Dalgliesh (1956). Indoles were located by dipping the dried chromatograms in Ehrlich's $p$-dimethylaminobenzaldehyde reagent (Jepson, 1955).

5-Hydroxyindolylacetic acid was determined in $24 \mathrm{hr}$. specimens of urine by the method of Udenfriend et al. (1955).

\section{RESULTS}

\section{Metabolism in rat-liver homogenates}

The chromatograms prepared from extracts of rat-liver homogenates incubated with 5-hydroxytryptamine showed four spots which stained purple with Ehrlich's reagent. Comparison of $R_{F}$ values in several solvent systems led to the identification of three of these as 5-hydroxytryptamine, indolylacetic acid and 5-hydroxyindolylacetic acid. The fourth substance, which also stained purple with Ehrlich's reagent, had a low $R_{F}$ in butanol-acetic acid-water. This enabled it to be separated from other indoles, so an attempt was made to isolate some of the material with the object of identifying it. 
Accordingly, 5-hydroxytryptamine creatinine sulphate $(120 \mathrm{mg}$.) was incubated with rat liver (63 g.) homogenized in Sørensen 0.067 M-phosphate buffer $(\mathrm{pH} \mathrm{7.4;120} \mathrm{ml.)} \mathrm{under} \mathrm{the} \mathrm{conditions}$ described above. After centrifuging, the supernatant was shaken with partially deactivated charcoal (6 g.) for $15 \mathrm{~min}$. The charcoal was collected by filtration, washed three times with water $(150 \mathrm{ml}$.$) and drained thoroughly, after$ which the indole derivatives were eluted six times with aqueous $6 \%(\mathrm{w} / \mathrm{v})$ phenol $(50 \mathrm{ml}$.). The solvent was removed as described above and a solution of the residue in aqueous $30 \%(\mathrm{v} / \mathrm{v})$ propan-2-ol (20 ml.) was applied to Whatman no. 1 chromatographic paper $(25 \mathrm{~cm} . \times 25 \mathrm{~cm}$.) as a $1 \mathrm{~cm}$. band about $2.5 \mathrm{~cm}$. from one edge: 15 sheets were required. After chromatography in butanolacetic acid-water by the ascending technique, the position of the band containing the unknown substance was located by staining with Ehrlich's reagent a strip cut from one of the chromatograms. The bands were then cut out and eluted with $30 \%$ $(\mathrm{v} / \mathrm{v})$ propan-2-ol $(60 \mathrm{ml}$.). The eluate was evaporated to dryness at $60^{\circ}$ under $3 \mathrm{~mm}$. $\mathrm{Hg}$ pressure. In order to remove a contaminating brown pigment the chromatographic procedure was repeated, the same solvent system being used. On evaporation the final eluate gave a colourless residue (129 mg.), which slowly turned brown on exposure to air. This was highly soluble in water and attempts to purify it by crystallization failed.

The crude material gave a brown colour with aniline hydrogen phthalate which suggested that it might be a glucuronide, but chromatography in butanol-pyridine-water (1:1:1, by vol.) demonstrated that the indole- and the aniline-reacting substances were distinct entities. It was subsequently shown that the unknown substance and glucuronic acid had identical $R_{F}$ values in the butanol-acetic acid-water mixture. The $R_{F}$ values of the hydroxyindoles detected in extracts of incubated liver homogenates are compared in Table 1.

Weissbach, Redfield \& Udenfriend (1958) detected 5-hydroxytryptamine $O$-glucuronide in the urine of mice treated with 5-hydroxytryptamine, and recently Keglević et al. (1959) have found the same substance in the urine of rats treated with 5-hydroxy $-\left[{ }^{14} \mathrm{C}\right]$ tryptamine. The latter workers reported that their conjugate had $R_{F} \quad 0 \cdot 10$ in butanol-acetic acid-water, a similar value to that obtained for the unknown substance during the present work, but in propan-2-ol-ammonia the $R_{F}$ values were quite different.

The crude product contained a substance which gave the ninhydrin-fluorescence test (Jepson \& Stevens, 1953) and showed a single absorption maximum at $275 \mathrm{~m} \mu$, but, unlike 5-hydroxytryptamine and 5-hydroxyindolylacetic acid, it did not give colour reactions with 1-nitroso-2-naphthol and nitrous acid nor with diazotized sulphanilic acid. Thus it appeared to be an indole derivative without a free phenolic hydroxyl group, and its low $R_{F}$ in butanol-acetic acid suggested that it might be a phenolic ester. Since the crude product contained sulphur it seemed likely that its main component might be the ester sulphate.

Attempts were therefore made to hydrolyse it by heating at $100^{\circ}$ with $3 \mathrm{~N}-\mathrm{HCl}$, but under these conditions extensive decomposition occurred. Satisfactory hydrolysis, however, was achieved by heating the crude material $(0.9 \mathrm{mg}$.$) with \mathrm{N}-\mathrm{HCl}$ $\left(2 \mathrm{ml}\right.$.) at $80^{\circ}$ for $20 \mathrm{~min}$. in a tube sealed to exclude oxygen. Subsequent chromatography demonstrated the presence of 5-hydroxytryptamine (approx. $0.1 \mathrm{mg}$.) in the hydrolysate. Further evidence in support of the view that the new metabolite was the ester sulphate of 5 hydroxytryptamine was obtained when $\mathrm{SO}_{4}{ }^{2-}$ ions were also detected in the hydrolysate. The acidic nature of the substance was shown by staining chromatograms of the original crude material with Universal Indicator (British Drug Houses Ltd.).

In order to exclude the possibility that the 5hydroxytryptamine creatinine sulphate used in the incubation experiments may have contained some sulphate in the form of ester, we repeated these experiments with the free base and obtained similar results. We were informed by the suppliers that their method of preparation of the creatinine sulphate precluded the possibility of esterification, and we also showed that the commercial product was chromatographically pure. Furthermore, we

Table 1. $R_{F}$ values of 5-hydroxyindoles detected by preparative paper chromatography in rat-liver homogenates incubated with 5-hydroxytryptamine

Chromatography was performed by the ascending technique on Whatman no. 1 paper at $22^{\circ}$.

\begin{tabular}{|c|c|c|c|}
\hline \multirow[b]{2}{*}{ Solvent system } & \multicolumn{3}{|c|}{$R_{F}$} \\
\hline & $\begin{array}{l}\text { 5-Hydroxy- } \\
\text { tryptamine }\end{array}$ & $\begin{array}{l}\text { 5-Hydroxyindolyl- } \\
\text { acetic acid }\end{array}$ & $\begin{array}{l}\text { Unknown } \\
\text { compound }\end{array}$ \\
\hline Butanol-acetic acid-water $(4: 1: 5$, by vol.) & $0 \cdot 40$ & $0 \cdot 73$ & $0 \cdot 11$ \\
\hline $20 \%(\mathrm{w} / \mathrm{v}) \mathrm{KCl}$ & $0 \cdot 34$ & $0 \cdot 49$ & $0 \cdot 68$ \\
\hline Propan-2-ol-aqueous $6 \mathrm{~N}$-ammonia $(20: 3, \mathrm{v} / \mathrm{v})$ & 0.58 & $0 \cdot 20$ & $0 \cdot 33$ \\
\hline Butanol-pyridine-water ( $1: 1: 1$, by vol.) & $0 \cdot 71$ & $0 \cdot 70$ & $0 \cdot 03$ \\
\hline
\end{tabular}


found that creatinine sulphate was not extracted from solutions of 5 -hydroxytryptamine creatinine sulphate by the method used.

An attempt was made to synthesize some authentic 5-hydroxytryptamine $O$-sulphate for comparison, but treatment of the base with sulphuric acid or chlorosulphonic acid under a variety of mild conditions failed to effect esterification. Paper chromatography showed that three and sometimes four products were obtained but all of these presumably contained free hydroxyl groups since they reacted with 1-nitroso-2-naphthol and nitrous acid to give the purple spots characteristic of 5-hydroxyindoles. None of these substances had the same $R_{F}$ values as the material obtained during the metabolic studies, and it seems that side reactions leading to ring substitution or the formation of sulphamic acids occurred in the course of our synthetic experiments.

\section{Enzymic hydrolysis of the new metabolite}

The crude ester sulphate $(500 \mu \mathrm{g}$.) obtained by preparative paper chromatography was completely hydrolysed by an acetone-dried powder of rat liver $\left(0 \cdot 2\right.$ g.) in sodium acetate buffer, $\mathrm{pH} 5 \cdot 2$, at $37^{\circ}$ in $24 \mathrm{hr}$. Subsequent paper chromatography showed that 5-hydroxytryptamine was the only indole derivative that could be detected. By contrast, the 'soluble' arylsulphatase preparation isolated from the acetone-dried powder by the method of Roy (1956) had no action on the material under these conditions.

\section{Investigation of the sulphate-synthesizing system}

An attempt was made to concentrate the sulphate-synthesizing systems by differential highspeed centrifuging of rat-liver homogenates. The supernatant fractions were incubated at $37^{\circ}$ for $24 \mathrm{hr}$. with mM-5-hydroxytryptamine in a medium shown by De Meio \& Lewycka (1955) to be capable of supporting enzymic ester sulphate synthesis (Sørensen 0.05 M-phosphate buffer, pH 7.0, containing $5 \mathrm{~mm}-\mathrm{MgCl}_{2}, 15 \mathrm{~mm}-\mathrm{Na}_{2} \mathrm{SO}_{4}$ and $5 \mathrm{~mm}$ adenosine triphosphate). The ester sulphate was separated by adsorption on charcoal followed by elution and paper chromatography as in the earlier experiments. The sulphate-synthesizing activity remained in the supernatant layer even when the applied centrifugal field was $24000 \mathrm{~g}$ for $30 \mathrm{~min}$. and would therefore appear to be associated with what Roy (1958) has described as the "microsomefree' fraction. Further fractionation showed that the activity was associated with a protein fraction precipitated by $1 \cdot 7-3 \cdot 5 \mathrm{M}-\left(\mathrm{NH}_{4}\right)_{2} \mathrm{SO}_{4}$.

No sulphate-synthesizing activity was observed when either the $\mathrm{Mg}^{2+}$ ions or adenosine triphosphate was omitted. Inorganic $\mathrm{SO}_{4}^{2-}$ ions were also essential.

\section{Urinary excretion of 5-hydroxyindole derivatives in rats injected with 5-hydroxytryptamine}

The urine from groups of three rats injected intraperitoneally with 5-hydroxytryptamine, or with iproniazid and 5-hydroxytryptamine, or with $\mathrm{Na}_{2} \mathrm{SO}_{4}$ and 5-hydroxytryptamine was extracted and subjected to preparative paper chromatography as in the homogenate experiments. Preliminary identification of the excreted indoles was achieved by applying the colour reactions previously described to two-dimensional paper chromatograms with butanol-acetic acid-water (4:1:5, by vol.) and $20 \%(\mathrm{w} / \mathrm{v}) \mathrm{KCl}$ as solvent systems.

Table 2 lists the indole derivatives found in rat urine after intraperitoneal injection of 5-hydroxytryptamine creatinine sulphate $(270 \mu$ moles $/ \mathrm{kg}$.$) .$ The substance 'unknown 2' appeared to be identical with the material provisionally identified as 5-hydroxytryptamine $O$-sulphate in the homogenate experiments, for it had the same $R_{F}$ values in three different solvent systems and it gave the same colour reactions. The substances 'unknown 1' and 'unknown 3' gave neither the ninhydrinfluorescence tests nor the 1-nitroso-2-naphtholnitrous acid test, but they reacted with Ehrlich's reagent. If these substances were in fact indole derivatives they did not possess free 5-hydroxyl groups.

The presence of the ester sulphate of 5-hydroxyindolylacetic acid was suggested by comparison of $R_{F}$ values with those reported by Snow et al. (1955), who previously detected this substance in the urines of patients with carcinoid disease. Some confirmation of the nature of this material was obtained by subjecting it to acid hydrolysis as described above, when it liberated free 5-hydroxyindolylacetic acid and $\mathrm{SO}_{4}{ }^{2-}$ ions.

The effect of repeated doses of 5-hydroxytryptamine on the excretion of metabolites in rat urine

Table 2. Urinary indoles excreted by rats injected with 5-hydroxytryptamine creatinine sulphate (270 $\mu$ moles $/ \mathrm{kg}$.)

Chromatography was performed by the ascending technique on Whatman no. 1 paper at $22^{\circ}$.
Substance detected

Indolylacetic acid

5-Hydroxyindolylacetic acid

Indolylacetylglutamine

Tryptophan

5-Hydroxyindolylacetic

acid $O$-sulphate

Unknown 3

Unknown 2

Unknown 1 
is shown in Table 3. The total recoveries of injected base during days 3-7 were $6.3 \mu$ moles (3\% of the dose) as 5-hydroxyindolylacetic acid, $27 \cdot 3 \mu$ moles $(13 \%)$ as 5 -hydroxyindolylacetic acid $O$ sulphate and $19 \cdot 1 \mu$ moles (9\%) as 5-hydroxytryptamine $O$-sulphate. Whereas the excretion of 5 hydroxyindolylacetic acid remained virtually constant throughout the injection period, a much greater proportion of the dose appeared as ester sulphates during the first $24 \mathrm{hr}$. of the experiment than on any subsequent day.

The provision of additional sulphate substantially reduced the falling off in the daily production of ester sulphates. In the experiments summarized in Table 4 the total recoveries of injected base during days 2-5 were $6.4 \mu$ moles (3\% of dose) as 5 -hydroxyindolylacetic acid, $41.5 \mu$ moles $(19 \%)$ as 5-hydroxyindolylacetic acid $O$-sulphate and $20.2 \mu$ moles $(9 \%)$ as 5 -hydroxytryptamine $O$-sulphate.

When the rats were pretreated with the amineoxidase inhibitor, iproniazid ( $20 \mathrm{mg}$./kg.), a marked change in the pattern of excretion was observed though the total recovery was unchanged. The results (Table 5) show that after the injection of a total of $71 \mu$ moles of 5-hydroxytryptamine, 18.2 $\mu$ moles (26\% of the dose) were excreted as 5-hydr-

Table 3. Effect of repeated administration of 5-hydroxytryptamine on the excretion of metabolites in rat urine

Experimental details are given in the text.

\begin{tabular}{|c|c|c|c|c|}
\hline \multirow[b]{2}{*}{ Day } & \multirow[b]{2}{*}{$\begin{array}{c}\text { 5-Hydroxy- } \\
\text { tryptamine } \\
\text { injected ( } \mu \text { moles/ } \\
\text { three rats) }\end{array}$} & \multicolumn{3}{|c|}{ Substances recovered from urine ( $\mu$ moles) } \\
\hline & & $\begin{array}{c}\text { 5-Hydroxy- } \\
\text { indolylacetic } \\
\text { acid }\end{array}$ & $\begin{array}{c}\text { 5-Hydroxy- } \\
\text { indolylacetic } \\
\text { acid } O \text {-sulphate }\end{array}$ & $\begin{array}{c}\text { 5-Hydroxy- } \\
\text { tryptamine } \\
\text { O-sulphate }\end{array}$ \\
\hline 1 & 0 & $0 \cdot 07$ & $\mathbf{0}$ & 0 \\
\hline 2 & 0 & 0.07 & 0 & 0 \\
\hline 3 & 71 & 1.56 & $12 \cdot 5$ & $11 \cdot 1$ \\
\hline 4 & 71 & $2 \cdot 03$ & $7 \cdot 3$ & $5 \cdot 2$ \\
\hline 5 & 71 & $1 \cdot 66$ & $5 \cdot 8$ & $2 \cdot 6$ \\
\hline 6 & 0 & 0.62 & 1.7 & 0.2 \\
\hline 7 & 0 & 0.42 & 0 & 0 \\
\hline 8 & 0 & $0 \cdot 20$ & 0 & 0 \\
\hline 9 & 0 & $0 \cdot 15$ & 0 & 0 \\
\hline
\end{tabular}

Table 4. Effect of sodium sulphate on the excretion of urinary indoles in rats repeatedly injected with 5-hydroxytryptamine

Experimental details are given in the text.

\begin{tabular}{ccc} 
Day & \multicolumn{2}{c}{$\begin{array}{c}\text { Substances injected } \\
(\mu \text { moles/three rats })\end{array}$} \\
\cline { 2 - 3 } $\begin{array}{c}\text { 5-Hydroxy- } \\
\text { tryptamine }\end{array}$ & $\mathrm{Na}_{\mathbf{2}} \mathrm{SO}_{4}$ \\
2 & 0 & 0 \\
3 & 71 & 21 \\
4 & 71 & 21 \\
5 & 71 & 21 \\
6 & 0 & 0 \\
& 0 & 0
\end{tabular}

\begin{tabular}{ccc}
\multicolumn{2}{c}{ Substances recovered from urine $(\mu \mathrm{moles})$} \\
$\begin{array}{c}\text { 5-Hydroxy- } \\
\text { indolylacetic } \\
\text { acid }\end{array}$ & $\begin{array}{c}\text { 5-Hydroxy- } \\
\text { indolylacetic } \\
\text { acid } O \text {-sulphate }\end{array}$ & $\begin{array}{c}\text { 5-Hydroxy- } \\
\text { tryptamine } \\
\text { O-sulphate }\end{array}$ \\
0.9 & 0 & 0 \\
$1 \cdot 1$ & $15 \cdot 2$ & $6 \cdot 0$ \\
$2 \cdot 7$ & $8 \cdot 2$ & $4 \cdot 4$ \\
$2 \cdot 1$ & $10 \cdot 1$ & $5 \cdot 4$ \\
0.5 & $8 \cdot 0$ & $4 \cdot 4$ \\
0.2 & 0 & 0
\end{tabular}

Table 5. Effect of iproniazid on the excretion of metabolites of 5-hydroxytryptamine in rat urine

Experimental details are given in the text.

Substances injected
(total dose/three rats)

$\overbrace{\begin{array}{c}\text { 5-Hydroxy- } \\ \text { tryptamine } \\ (\mu \text { moles })\end{array}}^{\begin{array}{c}\text { Iproniazid } \\ (\mathbf{m g} .)\end{array}}$

18

36

71

71

\begin{tabular}{|c|c|c|c|}
\hline & & \multicolumn{2}{|c|}{ Recovered from urine } \\
\hline \multicolumn{2}{|c|}{$\begin{array}{l}\text { 5-Hydroxyindolyl- } \\
\text { acetic acid }\end{array}$} & \multicolumn{2}{|c|}{$\begin{array}{l}\text { 5-Hydroxyindolyl- } \\
\text { acetic acid } O \text {-sulphate }\end{array}$} \\
\hline ( $\mu$ moles) & ( $\%$ of dose) & $(\mu$ moles $)$ & ( $\%$ of dose) \\
\hline 0.06 & 0 & 0 & 0 \\
\hline $1 \cdot 2$ & 7 & $3 \cdot 2$ & 17 \\
\hline $4 \cdot 0$ & 11 & $7 \cdot 4$ & 21 \\
\hline $5 \cdot 0$ & 7 & $13 \cdot 2$ & 19 \\
\hline $1 \cdot 8$ & $\mathbf{3}$ & $4 \cdot 9$ & 7 \\
\hline
\end{tabular}

5-Hydroxytryptamine $O$-sulphate

$\overbrace{(\mu \text { moles }) ~(\% \text { of dose })}$

Total recovery

(\% of dose)

0
0
0
$5 \cdot 1$
$14 \cdot 3$

0

0

0

20

0

24

32

33 
oxyindolylacetic acid and its ester sulphate and $5 \cdot 1 \mu$ moles $(7 \%)$ as 5 -hydroxytryptamine $O$ sulphate in the absence of iproniazid. In the presence of the inhibitor the acetic acid derivative and its $O$-sulphate formed only $10 \%(6 \cdot 7 \mu$ moles $)$ of the identified excretion products and the $O$ sulphate of 5-hydroxytryptamine was the major component, accounting for $20 \%$ (14.3 $\mu$ moles).

\section{Metabolites of 5-hydroxytryptophan in rat urine}

The excretion products detected in the urines of rats treated with 5-hydroxy-DL-tryptophan were qualitatively similar to those found after 5hydroxytryptamine was injected. Thus in addition to 5-hydroxyindolylacetic acid and its $O$-sulphate, the $O$-sulphate of 5 -hydroxytryptamine was also found. Unchanged 5-hydroxytryptophan, presumably the $\mathrm{D}$-isomer, was also detected, as were the normally occurring indole derivatives, indolylacetic acid, indolylacetylglutamine and tryptophan.

\section{Urinary indoles in human malignant carcinoid syndrome}

The urines of 14 patients with malignant carcinoid syndrome were found to contain high concentrations of 5-hydroxyindolylacetic acid (ranging from 38 to $646 \mathrm{mg} . / 24 \mathrm{hr}$.). These figures were paralleled by high blood concentrations of 5 hydroxytryptamine (ranging from 0.3 to $3.3 \mu \mathrm{g}$./ $10^{9}$ platelets). Other indoles detected by paper chromatography in most of these urines were indolylacetic acid, 5-hydroxyindolylacetic acid $O$ sulphate, tryptophan and indican, and in some we also found 5-hydroxytryptophan and indoleacetylglutamine. Several other unidentified minor components were observed on some of the chromatograms, but in no case did we find the ester sulphate of 5-hydroxytryptamine.

\section{DISCUSSION}

One of the results of our studies on the intermediary metabolism of 5-hydroxytryptamine in rat-liver preparations was that evidence of the formation of the hitherto-unknown ester sulphate was obtained. The enzyme system responsible for its synthesis was present in fractions prepared by high-speed centrifuging followed by salt precipitation. It was shown to require $\mathbf{M g}^{2+}$ ions, adenosine triphosphate and $\mathrm{SO}_{4}{ }^{2-}$ ions. Bernstein \& McGilvery $(1952 a, b)$ and De Meio \& Lewycka (1955) have previously reported the formation of the ester sulphates of phenol and dehydroepiandrosterone respectively in liver preparations, requiring the same cofactors. It would seem that the formation of the new metabolite by unfortified liver homogenates was probably due to the presence of sufficiently high concentrations of these factors. During salt precipitation of the protein containing the sulphate-synthesizing enzyme, however, these substances would remain in solution and would thus be separated from the purified enzymic fraction. These experimental results are consistent with the view that 'active sulphate' formation is probably the first step in the biosynthesis of sulphate conjugates (Hilz \& Lipmann, 1955; De Meio \& Wizerkaniuk, 1956), but we have not investigated the second step, i.e. sulphate transfer from 'active sulphate' to the phenol. This step may be substrate-specific.

Differential-centrifuging studies showed that the synthesizing system occurred in the 'microsomefree' supernatant. By contrast, the corresponding hydrolysing enzyme appeared to be associated with the microsomes. This is consistent with the findings of Baum \& Dodgson (1958), who have demonstrated that sulphate-synthesizing and -hydrolysing systems differ in thermal stability and other properties.

The detection of the ester sulphates of 5hydroxytryptamine and 5-hydroxyindolylacetic acid in rat urines is of interest in view of the occurrence of other indole sulphates in various biological systems. Indoxyl sulphate (indican) has long been known to occur in urine, especially in uraemia, and Wieland \& Voche (1930) isolated bufothionine [3-(2-dimethylaminoethyl)-5-hydroxyindole sulphate] from toad venom. Chromatographic evidence for the presence of the ester sulphate of 5-hydroxyindolylacetic acid in the urine of patients with carcinoid disease has been reported by Snow et al. (1955), an observation confirmed during similar studies in this Laboratory.

The presence of 5-hydroxytryptamine $O$-sulphate was found in rat urines after the intraperitoneal administration of $270 \mu$ moles of 5-hydroxytryptamine/kg. but it was not detected after smaller doses (Table 5). The sulphate of 5-hydroxyindolylacetic acid, however, was found in every case irrespective of the dose. It would appear that 5-hydroxytryptamine $O$-sulphate is the product of a detoxicating mechanism which operates only at relatively high concentrations. The failure to detect the ester sulphate of 5-hydroxytryptamine in human carcinoid urine implies that the amount of the base produced by the tumours was apparently not sufficiently great to bring such a process into action. On the other hand, this mechanism may not operate in man. Our quantitative studies in rats accord with the results of Udenfriend, Titus, Weissbach \& Peterson (1956), who found that only about $30 \%$ of 5 -hydroxytryptamine injected into dogs was excreted as urinary 5-hydroxyindolylacetic acid. In our experiments the relatively high proportion of 5-hydroxyindolylacetic acid excreted as ester 
sulphate (Table 5) may be partly due to the presence of creatinine sulphate in the material injected. The site of injection may also be important in this connexion, for intestinal tissue has been shown to contain sulphate-conjugate-synthesizing systems (Pasternak, Kent \& Davies, 1958). The effect of these may be potentiated when the intraperitoneal route is used.

Prior administration of iproniazid inhibited the amine-oxidase pathway and, when 5-hydroxytryptamine was subsequently injected, there was a considerable increase in the excretion of ester sulphate above that found in control animals not treated with iproniazid. Friend, Zileli, Hamlin \& Reutter (1958) have reported a similarly increased excretion of the ester sulphate of noradrenaline in the urines of patients treated with iproniazid. It might be expected that the effects of a pharmacologically active amine might be enhanced by simultaneous administration of an amine-oxidase inhibitor. Friend et al. (1958) were unable to detect such enhancement, however, and our results suggest that this may be due to the diversion of the metabolism of the amine to pathways which do not involve amine oxidase.

The identification of the ester sulphate of 5 hydroxytryptamine in the urines of rats treated with 5-hydroxytryptophan provides additional evidence that this substance is a precursor of 5 . hydroxytryptamine in vivo. The conversion of 5hydroxytryptophan into the corresponding amine has been demonstrated in vitro by Gaddum \& Giarman (1956) and by Udenfriend et al. (1956). In addition, the latter workers found that administration of $\left[2-{ }^{14} \mathrm{C}\right]$ tryptophan to rabbits led to the formation of labelled 5-hydroxytryptamine, which was detected in the platelets.

Udenfriend et al. (1956) also showed that radioactive 5-hydroxyindolylacetic acid was excreted in the urine of a patient with carcinoid disease after the administration of $\left[{ }^{14} \mathrm{C}\right]$ tryptophan. This, however, cannot by itself be regarded as a direct proof of the formation of 5-hydroxytryptamine from 5hydroxytryptophan, for the acetic acid derivative might arise by routes which do not require the amine as an intermediate, e.g. transamination followed by oxidative decarboxylation. The demonstration of the formation of the $O$-sulphate of 5 hydroxytryptamine during the present work suggests that such alternative routes are unlikely to be important.

\section{SUMMARY}

1. A major product of the metabolism of 5 hydroxytryptamine in rat-liver homogenates has been provisionally identified as the ester sulphate.

2. A protein fraction, prepared from rat-liver homogenates by differential centrifuging and salt precipitation, has been shown to possess sulphatesynthesizing activity. Essential requirements were adenosine triphosphate, $\mathrm{Mg}^{2+}$ and $\mathrm{SO}_{4}{ }^{2-}$ ions.

3. The ester was hydrolysed by a sulphatase present in acetone-dried powders of rat-liver tissue, but an aqueous extract of the powder did not contain this sulphatase.

4. In rats only about $30 \%$ of administered 5 hydroxytryptamine was recovered as 5-hydroxyindolylacetic acid, some $70 \%$ of which was excreted as ester sulphate. The ester sulphate of 5 hydroxytryptamine was excreted in rat urine only after large doses $(270 \mu$ moles $/ \mathrm{kg}$. $)$.

5. Experiments with rats pretreated with iproniazid suggest that sulphate formation is an alternative pathway for the metabolism of 5-hydroxytryptamine when the normal route involving amine oxidase is inhibited or saturated.

6. In the rat the availability of $\mathrm{SO}_{4}{ }^{2-}$ ions proved to be a limiting factor for 5-hydroxytryptamine $O$-sulphate production.

7. The $O$-sulphate of 5 -hydroxytryptamine was also found in the urines of rats treated with 5hydroxytryptophan, thus providing further evidence that this substance is a precursor of the amine in vivo.

We thank Dr J. Marks of Roche Products Ltd. for providing the iproniazid. The work was aided by grants from the Endowment Funds of Westminster Hospital.

\section{REFERENCES}

Baum, H. \& Dodgson, K. S. (1958). Nature, Lond., 181, 115. Bernstein, S. \& McGilvery, R. W. (1952a). J. biol. Chem. 198, 195.

Bernstein, S. \& McGilvery, R. W. (1952b). J. biol. Chem. 199, 745.

Blaschko, H. (1952). Biochem. J. 52, x.

Bruce, H. M. \& Parkes, A. S. (1949). J.Hyg., Camb., 47, 202.

Chadwick, B. T. \& Wilkinson, J. H. (1958). Biochem. J.68, 1 P.

Dalgliesh, C. E. (1956). Biochem. J. 64, 481.

Dalgliesh, C. E. \& Dutton, R. W. (1957). Biochem. J. 65, $21 \mathrm{P}$.

De Meio, R. H. \& Lewycka, C. (1955). Endocrinology, 56, 489. De Meio, R. H. \& Wizerkaniuk, M. (1956). Biochim. biophys. Acta, 20, 428.

De Meio, R. H., Wizerkaniuk, M. \& Schreibman, I. (1955). J. biol. Chem. 213, 439.

Dodgson, K. S. \& Spencer, B. (1953). Biochem. J. 55, 316. Friend, D. C., Zileli, M. S., Hamlin, J. T. \& Reutter, F. W. (1958). J. clin. exp. Psychopath. (Suppl. 19), 61.

Gaddum, J. H. \& Giarman, M. J. (1956). Brit. J. Pharmacol. 11, 88.

Hilz, H. \& Lipmann, F. (1955). Proc.nat. Acad.Sci., Wash., 41, 880 .

Hogeboom, G. H. (1955). In Methods of Enzymology, vol. 1, p. 16. New York: Academic Press Inc.

Jepson, J. B. (1955). Lancet, ii, 1009.

Jepson, J. B. \& Stevens, B. J.(1953). Nature, Lond., 171, 772. 
Keglević, D., Supek, Z., Kveder, S., Iskrić, S., Kečkeš, S. \& Kisić, A. (1959). Biochem. J. 73, 53.

Pasternak, C. A., Kent, P. W. \& Davies, R. E. (1958). Biochem. J. 68, 212.

Roy, A. B. (1956). Biochem. J. 62, 41.

Roy, A. B. (1958). Biochem. J. 68, 519.

Snow, P. J. D., Lennard-Jones, J. E., Curzon, G. \& Stacey, R. S. (1955). Lancet, ii, 1004.
Titus, E. \& Udenfriend, S. (1954). Fed. Proc. 13, 411.

Udenfriend, S., Titus, E. \& Weissbach, H. (1955). J. biol. Chem. 216, 499.

Udenfriend, S., Titus, E., Weissbach, H. \& Peterson, E. (1956). J. biol. Chem. 219, 335.

Weissbach, H., Redfield, B. C. \& Udenfriend, S. (1958). Fed. Proc. 17, 418.

Wieland, H. \& Voche, F. (1930). Liebigs Ann. 481, 215.

Biochem. J. (1960) 76, 109

\title{
Toxic Liver Injury
}

\section{INHIBITION BY DIMETHYLNITROSAMINE OF INCORPORATION OF LABELLED AMINO ACIDS INTO PROTEINS OF RAT-LIVER PREPARATIONS IN VITRO}

\author{
By T. HULTIN, E. ARRHENIUS, H. LÖW AND P. N. MAGEE* \\ Wenner-Gren Institute, University of Stockholm, Sweden
}

\section{(Received 7 October 1959)}

Dimethylnitrosamine ( $N$-nitrosodimethylamine) has been shown to cause acute centrilobular necrosis of the liver in several mammalian species, including the rat (Barnes \& Magee, 1954). It is carcinogenic in the rat, producing tumours of the liver (Magee \& Barnes, 1956; Schmähl \& Preussmann, 1959) and of the kidney (Magee \& Barnes, 1959; Zak \& Holzner, 1959). The compound is rapidly metabolized in vivo (Magee, 1956; Dutton \& Heath, 1956; Heath \& Dutton, 1958) and in vitro by liver slices and broken-cell preparations (Magee \& Vandekar, 1958). When given to rats in doses sufficient to cause necrosis of the liver $(50 \mathrm{mg} . / \mathrm{kg}$. body wt.) incorporation of isotopically labelled amino acids into liver proteins was greatly reduced $3 \mathrm{hr}$. after the administration of the poison, but no effect was observed in other organs. At this time, histological evidence of damage to the liver was minimal or absent. A smaller inhibition of incorporation of ${ }^{32} \mathrm{P}$ into the liver ribonucleic acid also occurred, but labelling of the acid-soluble and the lipid phosphorus was not affected nor was the concentration of liver glycogen. It was concluded that the structures, giving rise to the microsomes, may be particularly vulnerable to the damaging action of dimethylnitrosamine (Magee, 1958).

The present paper describes the effect of dimethylnitrosamine on the incorporation of labelled precursors into proteins and nucleic acids of ratliver slices in vitro, and the effect of pretreatment of the animals with the compound on the capacity of cell-free preparations of liver to incorporate

* Present address: Toxicology Research Unit, M.R.C. Laboratories, Woodmansterne Road, Carshalton, Surrey. labelled amino acids into proteins. Experiments with isolated mitochondria are also described. A preliminary account of this work has already been given (Hultin, Magee \& Arrhenius, 1958).

\section{MATERIALS AND METHODS}

\section{Chemical reagents}

Dimethylnitrosamine. This was obtained commercially and purified by distillation (b.p. $151^{\circ}$ ). After suitable dilution with water it was given to rats by stomach-tube. The dose was $50 \mathrm{mg} . / \mathrm{kg}$. body wt. unless otherwise stated. It was estimated in tissue samples by the polarographic method of Heath \& Jarvis (1955).

Radioactive compounds. DL- $\left[4-{ }^{14} \mathrm{C}\right]$ Valine, L- $\left[{ }^{14} \mathrm{C}\right]$ leucine (generally labelled), [8-14 C]adenine sulphate and [ [22 P]phosphate were supplied by The Radiochemical Centre, Amersham, Bucks., England. [ $\left.{ }^{32} \mathrm{P}\right]$ Pyrophosphate was prepared by prolonged héating of $\mathrm{K}_{2} \mathrm{H}^{32} \mathrm{PO}_{4}$ at $325^{\circ}$.

Speciat reagents. Yeast hexokinase was prepared essentially according to Berger, Slein, Colowick \& Cori (1946). Phosphoenolpyruvate was synthesized by the method of Ohlmeyer (1951). Adenosine 5iphosphate (AMP) and adenosine triphosphate (ATP) were obtained from the Sigma Chemical Company, St Louis, Mo., U.S.A., and crystalline bovine-plasma albumin from Armour Laboratories, Chicago, Ill., U.S.A.

\section{Experiments on tissue slices}

Albino rats of the Wistar strain were maintained on a diet of vitamin-enriched rat-bread (Lindberg, Älvsjö, Sweden), and were killed by decapitation.

Male rats, usually weighing about $250 \mathrm{~g}$., were starved overnight before use. Their livers or kidneys were rapidly removed and placed in ice-cold Krebs-Henseleit (1932) medium. Thin slices were cut with a razor blade fixed in a holder, with"a..device not previously described (Fig. 1). 